\title{
Discussion on the Development of School-Enterprise Cooperation under the Practice Teaching of Design Major of Colleges and Universities
}

\author{
Hui $\mathrm{Mu}^{1,2}$ \\ ${ }^{1}$ College of Fashion and Design \\ ${ }^{2}$ Key Laboratory of Clothing Design \& Technology \\ Donghua University \\ Shanghai, 200051, China \\ yezpnj@126.com
}

\begin{abstract}
The transformation of the information society has driven the rapid development of the design industry, and the school-enterprise cooperation, as a mode of modern education reform, plays an important role in the cultivation of talents in design majors of colleges and universities. This work firstly analyzed the development necessity of the school-enterprise cooperation, studied the different demands of the society, industry, universities and enterprises at the present stage, then discussed the practice teaching mode of school-enterprise cooperation in design majors of universities, and finally put forward the inspiration of establishing the interaction mechanism between schools and enterprises that broke tradition and building the platform of design industry.
\end{abstract}

Keywords-school-enterprise cooperation; design major; teaching mode; practice teaching

\section{INTRODUCTION}

School-enterprise cooperation first emerged in western countries. The initial research mainly focused on the form and characteristics of school-enterprise cooperation, and the innovative theoretical fields of industry-university-research. It was gradually introduced into teaching models such as "Cooperative Education" in the United States, and "Dual system education" in Germany. Western countries emphasize students' practical ability, introduced school-enterprise cooperation in design majors teaching earlier. In China, as a universal mode of modern education and teaching reform, school-enterprise cooperation has achieved results in science and engineering colleges, but it is still in the development stage of design teaching. On the one hand, it presents a richer and more diverse form of cooperation. On the other hand, we also need to constantly explore and think about promoting its healthy development.

\author{
Yumei Cui ${ }^{1,2} *$ \\ ${ }^{1}$ College of Fashion and Design \\ ${ }^{2}$ Key Laboratory of Clothing Design \& Technology \\ Donghua University \\ Shanghai 200051, China \\ cymyhyez@126.com \\ *Corresponding author
}

\section{ThE DEVELOPMENT NECESSITY OF SCHOOL- ENTERPRISE COOPERATION IN DESIGN MAJOR}

\section{A. The Talent Training Demand of the Social Development}

With the coming of the information age, talents and education have become the key to accelerate the transformation and upgrading of the national economy and society. The demand of the society for talents is higher talents with certain practical and innovative abilities. For the design graduates under the cultivation of higher education, they shall have a certain academic foundation, meanwhile, they can flexibly apply it to the social practice and match with the social needs, which is the key to strengthen the construction of higher education in China [1].

Outline of National Medium and Long-Term Program for Education Reform and Development (2010-2020) aims at higher education and puts forward "establishing a new mechanism of training talents jointly by colleges and universities, scientific research institutes, industries and enterprises". For the reform of talent training system, it emphasizes "close cooperation among schools, families and society, and strengthening cooperation among schools, enterprises and scientific research institutions". As a cooperation mode between schools and enterprises, schoolenterprise cooperation meets the needs of the reform and development of higher education and the economic and social development of our country, is in line with the needs of the society, satisfies the practical and effectiveness training of talents, and is of great significance to improve the quality of talent training and perfect the education talent training system in China [2].

\section{B. The Talents Training Demand of Design Industry}

Due to the practical characteristics of the design industry, it needs the designers to be capable of transforming design concepts into commodities on the basis of meeting the market rules. It requires design students of colleges and universities to increase their practical ability to market projects, combine theory with practice, and integrate design with the market. For 
example: fashion design involves fashion trend analysis, theme planning, series design, clothing pattern making and so on. Graphic design companies also need to comprehensively understand the demands of the market and customers. Divorcing from the understanding and control of the practice, the design can not be better utilized by people, and can not be converted into products.

Design enterprises tend to have employees with certain working experience, and it's because they can transform design ideas into commodities, and can be adopted by the market at the same time. Therefore, the colleges and universities and enterprise docking platform established by school-enterprise cooperation strengthens the students' ability to practice design, and more specifically exports talents for the design industry.

\section{Complementary Development Demands of Colleges and Universities and Enterprises}

School-enterprise cooperation complements the resources of the two main bodies of colleges and universities and enterprises. On the one hand, it reduces the cost of personnel training in universities and widens the employment channels of students; on the other hand, it transports talents to enterprises and improves the popularity of enterprises. School-enterprise cooperation meets the development demands of both sides, and it is a win-win and common development cooperation mode.

\section{1) Interest Appeal of Colleges and Universities}

Higher education is a specialization education oriented to social demands. It aims to meet the demands of relevant stakeholders, including promoting the employment of students, providing qualified special talents for the industry, and fully implementing the national human resources strategy [3].

Under the requirements of the social environment at the current stage, the design majors in colleges and universities need to cultivate talents with both personalized thinking and comprehensive practical ability, so as to help students to obtain employment and transport talents to enterprises. Therefore, colleges and universities pay more attention to the targeted training of design professional talents: in terms of theory, they shall have a solid reserve of knowledge about design history and design principles; in terms of ability, they are capable of transforming design concepts into products through practice, taking the training direction of clothing design as an example that it shall cultivate talents with knowledge and skills reserve related to art, clothing pattern making, process production and ergonomics, etc. to better assist the design practice. Enterprises provide a good hotbed for the cultivation of design talents in colleges and universities. From design to production, their complete design process and professional resources and equipment, combined with the theoretical teaching in colleges and universities, are conducive to the better implementation of the national talent training strategy in colleges and universities, while providing comprehensive talents for the industry. Therefore, the school-enterprise cooperation satisfies the training objectives of university design majors to the maximum degree.

\section{2) Interest Appeal of Design Enterprises}

The interest appeal of enterprises is to pursue the maximization of their own economic interests [4]. In the school-enterprise cooperation, the acquisition of their own interests is mainly divided into the following points: first, design and development costs. In design enterprises, product or design scheme is the core of the enterprise. Most of the schoolenterprise cooperation courses of design majors will carry out product design practice or design scheme based on enterprise theme. Novel design ideas open up the design ideas for enterprises, and excellent design products will be put into the enterprise's production. Therefore, the classroom of schoolenterprise cooperation is a new path for the $R \& D$ of the design enterprises. Second, the cost of talent recruitment and training. The teaching mode of school-enterprise cooperation, such as on-the-job internship, can reduce the human resource expenditure of enterprises. In addition, in the internship stage, enterprises can retain excellent talents as regular employees, at the same time, it will reduce the cost of enterprise training. Third, direct remuneration. Some colleges and universities will provide service fees, design resource usage fees and other remuneration for enterprises that come to the colleges and universities to conduct theoretical or practical teaching. Fourth, publicity cost. The communication and cooperation between the enterprise and the school, to some extent, publicize for the enterprise. As a design company, it also publicizes the brand products invisibly and improves the enterprise's popularity and core competitiveness.

\section{Practice Teaching Mode OF SCHOOL-EnTERPRISE COOPERATION IN DESIGN MAJOR}

\section{A. Long Term Cooperation Mode and Phased Cooperation Mode}

The long-term cooperative school running has the characteristics of comprehensiveness and systematization. The main mode of long-term cooperation in running school is to establish a school level design and experiment center or practical education base outside the school, and to carry out the training of higher talents with the experiment center and practice base as the center. First of all, in the long-term cooperation mode, colleges and universities and enterprises better integrate the resources of both sides, provide stable equipment and resources, and systematic curriculum planning for talent training, which is more conducive to the healthy operation of talent training mechanism. Secondly, through the long-term platform established by the school-enterprise cooperation, the enterprise will transfer the type of needed design talents to the school, and the school will adjust the setting and teaching of the design courses according to the demands of the enterprise, so as to cultivate the design talents more in line with the demands of the enterprise and the industry. In the long-term courses of school-enterprise cooperation, enterprises absorb and reserve talents through observation. At the same time, students of colleges and universities are able to have a more systematic understanding of the design industry, contact the market earlier, understand and control the market demand, and lay a solid foundation for employment.

Phased cooperative school running is a joint training for the needs of specific phase in the cultivation of colleges and universities. Compared with the long-term cooperation mode, 
the phased cooperative school running is more flexible, and the education and teaching for a certain module is more targeted. It is easy to choose and control for design majors. For example, if the product company brings the new product development of a certain phase into the phased cooperation teaching, it first tells the students the positioning and product style of the enterprise, then conveys the design requirements and assists the college and university to complete the tutorial teaching of design. After the students complete the product design, the enterprise facilitates its own resource advantages to cooperate with the students to complete good product production. Such phased teaching can not only make enterprises acquire good creativity and design, but also enable students to complete the practice from design to production. However, at the same time, there are some disadvantages in the phased cooperative school running. The short-term cooperation is difficult to make the colleges and universities and the enterprise highly consistent, and it still needs continuous communication and adjustment between the two sides to achieve better cooperation results.

No matter long-term cooperation mode or phased cooperation mode, both of them are based on the cultivation plan of the colleges and universities. Only choosing schoolenterprise cooperation matching with industry courses based on the actual situation can lay a solid foundation for school enterprise cooperation.

\section{B. Competition or Project Cooperation Mode}

The design competition held by the cooperation of colleges and universities is one of the important entry points for schoolenterprise cooperation. Through the platform of design competition, students can show their personal professional quality and design practice skills, and enterprises can get the opportunity to select high-quality talents. It is not only beneficial for students to develop their own career direction, but also conducive for enterprises to develop design reserve talents, and at the same time, it also strengthens the cultivation of talents in colleges and universities. The world-famous 3M enterprises and the College of Fashion and Design, Donghua University have been carrying out close competitions and project cooperation since 2014. In order to encourage the development and progress of China's textile industry, 3M China Co., Ltd. and Donghua University have jointly held four sessions of "3M Thinsulate - Donghua Cup" open creative competition. Every year, different subjects were adopted to let clothing graduate students to innovate the application of Thinsulate TM thermal insulation materials. The holding of the fashion design competition by $3 \mathrm{M}$ enterprise and Donghua University aimed to encourage Donghua students to make full use of their professional advantages, combined with new Thinsulate TM thermal insulation materials, to practice and apply creative design, meanwhile, it also injected new research and development ideas into 3M Thinsulate.

Through cooperation with enterprises, design colleges and universities turning design projects into research projects is another form of school-enterprise cooperation. The school running mode integrating industry-school-research is a school running mechanism that is more conducive for the colleges and universities and enterprises reaching mutually beneficial and common development. Jiangnan University and Bosideng
Group have been strategic partners for many years. They have close cooperation in the aspects of industry-school-research cooperation, talent training, and glorious education and so on. In 2019, Bosideng Group has set up "Jiangnan University Bosideng Group High-End Down Product R \& D Center" in Jiangnan University. Both parties signed a memorandum of industry-school-research cooperation, deepened $R \quad \& \quad D$ cooperation on high-end down products of Bosideng Group in terms of postdoctoral workstation, technological innovation and R \& D, construction of scientific and technological talent team, development of functional fabrics, etc., to build a technological innovation system with enterprises as the main body, market-oriented and the combination of industry-schoolresearch. Although the project cooperation in school-enterprise cooperation integrates industry-school-research, which is more conducive to $R \& D$ and production of the products, it also needs a large amount of capital investment. In the implementation of the project, it needs a large number of manpower and material resources, has higher requirements for the enterprise itself, and the joining of colleges and universities effectively reduces part of the cost. In general, the project cooperation between enterprises and universities will complement each other's resources, accumulate practical experience for students and solve practical problems in the project for enterprises.

\section{On-the-job Internship Cooperation Mode}

On-the-job internship refers to the school-enterprise cooperation mode in which the cooperative enterprise provides relevant jobs for students of colleges and universities and students can work while learning. During the on-the-job internship, the design students mainly take the relevant positions of design assistants. During the internship, the students can understand the complete process of "investigation and research - planning - development - pattern makingproduction" of the enterprise, can contact experienced designers, technologists and other personnel, enhance the practical application of various skills, and comprehensively improve their professional skills and professional quality. Some posts also provide opportunities for excellent students to become regular, and provide more choices for the employment of design students in colleges and universities. At the same time, the on-the-job internship reduces the cost of human resources to a certain extent, and creates a high-quality environment for mining high-quality design reserve talents.

\section{THE INSPIRATION OF SCHOOL-ENTERPRISE CoOperation to the Practice TEACHING OF DESIGN MAJORS}

\section{A. To Build and Break the Traditional School-Enterprise Interaction Mechanism}

At the current stage, our country is in the period of highspeed development of higher design education. The innovation of school-enterprise interaction mechanism is an effective way and inevitable choice for higher education to enhance its vitality and cultivate high-quality design talents that meet the demands of social development. From the initial establishment of the enterprise training base outside the school to the introduction of design competitions or projects at the current 


\section{CONCLUSION}

stage, the talent training mode of school-enterprise cooperation has been continuously innovated, enhancing the vitality of school running and the participation of students. In the next step, to further enhance the interaction of school-enterprise cooperation, it shall introduce and establish school-enterprise cooperation professional teacher team and organization. According to the characteristics of design majors focusing on $\mathrm{R}$ \& D and practice, the form of design competitions and schoolenterprise $\mathrm{R} \& \mathrm{D}$ projects shall change the forms, the cultivation of students' independent learning capability and innovation practice capability shall be enhanced, so as to meet the needs of diversified and personalized development of the students.

\section{B. To Build Demand-Oriented Design Industry Platform}

Industry platform refers to social media to provide services, communication, coordination, supervision and other works between the government, colleges and universities and enterprises. In the teaching mode of school-enterprise cooperation, professional and comprehensive design industry platform is an important link between universities and enterprises, which can effectively promote the development of school-enterprise cooperation in the design industry.

On the basis of school-enterprise cooperation in running schools, rely on the strength of the government, promote the establishment of school-enterprise cooperation management institutions in various regions, and build regional to national industry platform for school-enterprise cooperation [5]. Under the industry platform, collect the information of colleges and universities, enterprises and social organizations according to the region, carry on the unified coordination and the stratification division to the running school projects of schoolenterprise cooperation, and construct the innovation platform for entire design professional practice. At the same time, we should give full play to and make use of the two different educational environments and resources of colleges and universities and enterprises to mobilize and integrate the social resources of the design industry [6]. Let more and more highquality colleges and universities and design industry enterprises have the opportunity to dock and cooperate. According to the resource conditions of both parties, carry out school-enterprise cooperation to cultivate talents in a selective and targeted way, expand social cognitive channels for school-enterprise cooperation on school running and talent training, and enhance the public's enthusiasm for school-enterprise cooperation.

The teaching mode of school-enterprise cooperation requires colleges and enterprises to establish a long-term strategic layout and look to the future, so as to establish indepth school-enterprise cooperation and achieve long-term mutual benefit and win-win.
This work shows that school-enterprise cooperation in design majors is a common demand of our society, industry, schools and enterprises, and it is also the trend of future education reform. The design school-enterprise cooperation model in China is diversified, so it is necessary to establish a deep school-enterprise cooperation mechanism with clear division of labor and coordinated development. To improve the deep school-enterprise cooperation, breaking the productionstudy-research cooperation education system as the starting point, mobilizing the enthusiasm of schools and enterprises, and relying on government supervision and coordination, so as to encourage all parties to make full use of their own advantageous resources and build a design industry platform, training outstanding design talents for society.

\section{ACKNOWLEDGMENTS}

The authors would like to acknowledge financial support from the following project.

1. Research base of the cross-border Art on Shanghai style, DD18002

2.Fundamental Research Funds for the Central Universities, 2232019G-08

3.Key course construction project of Shanghai Education C ommission: Apparel Design VII - Children's Apparel Design, 107-20-0007048

4.Intangible cultural heritage clothes\&accessories cultural h eritage and urban fashion

\section{REFERENCES}

[1] Sun Fuquan, Chen Baoming and Wang Wenyan. Innovation of IndustrySchool-Research Cooperation in Major Developed Countries-Basic Experience and Enlightenment [M]. Economy \& Management Publishing House, 2008.

[2] Jiang Yan. Overview of Contemporary International Higher Education [M]. Lanzhou: Lanzhou University Press, 2002.

[3] Wang Xiaobao, Zeng Mingxing, Zhou Qingping, Xu Hongzhi and Qian Jiang. Research on Benefit Mechanism of School-Enterprise Cooperation [J]. Experimental Technology and Management, 2014, 31 (02): 146-150.

[4] Zhang Jing and Zhou Yi. Exploring the Way of Cultivating Practical Talents in Design-Learning from Foreign School-Enterprise Cooperation Mode [J]. Leather Science and Engineering, 2012, 22 (06): 74-77.

[5] Gao Hongmei. Study on Mode of School-Enterprise Cooperation from the Perspective of Win-Win Culture [D]. Hebei Normal University, 2012.

[6] Liu Chang'an, Bai Yixian and Yang Kai. Constructing the Talent Training Mode of "Demand-Oriented and School-Enterprise Cooperation" Industry Characteristic University [J]. China University Teaching, 2016(01):36-41. 